\title{
Rapid and cost-effective method for micro- organism enumeration based on miniaturization of the conventional plate-counting technique
}

\author{
Florence BARON*, Marie-Françoise COCHET, Wilfried ABLAIN, \\ Noël GROSSET, Marie-Noël MADEC, Fabienne GONNET, \\ Sophie JAN, Michel GAUTIER
}

UMR Science et Technologie du Lait et de l'Euf, Équipe de Microbiologie, Agrocampus Rennes-Inra, 65 rue de Saint Brieuc, 35042 Rennes, France

Received 9 September 2005 - Accepted 6 March 2006

\begin{abstract}
The conventional plate-counting technique, while still routinely used in laboratories requiring micro-organism screening or enumeration, remains time-consuming and tiresome for the operator when large numbers of samples are assayed. We developed a miniaturized method based on serial tenfold dilution of samples in 96-well micro-plates followed by multiple pour-plating into 24-well micro-plates with an agar overlay procedure, providing easy colony counting and interpretation. The accuracy, sensitivity and reproducibility of this miniaturized method were tested using the conventional plate-counting technique as reference for viability measurements of Escherichia coli cells submitted to a sub-lethal thermic stress, enumeration of lactic bacteria during milk fermentation, and analysis of the total aerobic flora, coliform and Staphylococcus aureus content of spoiled food. No significant differences were found between the results obtained with our miniaturized method and the conventional one, regardless of the bacteria and media used. Providing a reduction in overall cost and handling time, this reliable miniaturized method should be useful for experiments involving large ranges of cell concentration as well as great numbers of samples and replicates.

micro-organism counting / pour-plate enumeration / miniaturized method

摘要 - 基于常规技术微型化的一种快速有效的微生物计数方法。目前试验室中进行微生物 篮选或计数仍然使用常规的平板计数方法, 当分析大批量的样品时, 这种方法就显得费时 而且枯燥。为此我们在常规平板计数的基础上研究了一种微型化微生物计数方法, 首先样 品在 96 孔微滴板盘中连续进行 10 倍稀释后, 取一定量不同稀释倍数的样品接种到 24 孔微 滴盘中并用琼脂快速覆盖, 经培养后计算菌落总数。为了评价该微型化方法的精确性、灵 敏性和重现性, 分别采用该方法和常规平板计数法测定了大肠杆菌在亚致死温度下的存活 情况, 牛乳发酵过程中乳酸菌数的变化, 以及腐败食品中总需氧菌数、大肠菌群数和金黄 色葡萄球菌数。实验结果表明, 两种方法测定结果之间没有显著性的差异, 并且测定结果 不受微生物种类和培养基类型的影响。该方法准确、经济、省时, 适合于测定细胞浓度变 化范围较大、测定样品数较多且需要重复的实验。
\end{abstract}

微生物计数 / 平板计数法 / 微型化方法

\footnotetext{
* Corresponding author (通讯作者): baron@agrocampus-rennes.fr
} 
Résumé - Développement d'une méthode de dénombrement microbien rapide et peu coûteuse basée sur la miniaturisation de la méthode classique de dénombrement après culture sur gélose. La méthode classique de dénombrement des micro-organismes après culture en milieu gélosé est toujours très utilisée dans les laboratoires de microbiologie. Elle est cependant coûteuse en temps et devient fastidieuse pour des études mettant en jeu un grand nombre d'échantillons et/ou nécessitant de nombreuses répétitions. Nous avons développé une méthode miniaturisée basée sur le même principe que la méthode classique mais utilisant des plaques 96 puits pour la phase de dilution décimale des échantillons et des plaques 24 puits pour la phase d'ensemencement des dilutions dans l'agar, ceci permettant le traitement d'un grand nombre d'échantillons en gardant la même facilité de comptage et d'interprétation des colonies. La fiabilité, la sensibilité et la reproductibilité de cette méthode miniaturisée ont été vérifiées en utilisant la technique conventionnelle comme référence pour des dénombrements de cellules d'Escherichia coli soumises à un traitement thermique subléthal, de bactéries lactiques au cours de la fermentation du lait en yaourt et de la flore mésophile, des coliformes totaux et de Staphylococcus aureus dans des aliments. Aucune différence significative n'a été mise en évidence entre les résultats obtenus par les deux méthodes, quels que soient les bactéries et le milieu de culture. Cette microméthode de dénombrement après culture en milieu gélosé permet donc des réductions de coût et de temps de manipulation avec la même fiabilité que la méthode classique. Elle peut donc être utile pour toutes les expériences impliquant une gamme étendue de concentrations bactériennes ainsi qu'un grand nombre d'échantillons et de répétitions.

dénombrement microbien / ensemencement dans la masse / microméthode

\section{INTRODUCTION}

The increasing need for rapid cell enumeration in food microbiology has prompted the development of rapid and economical methods. These developments are based upon quantification of cell metabolic activity such as impedancemetry, radiometry, microcalorimetry and ATPmetry or detection of specific cell molecules or genes by immunological or PCR methods. The conventional plate-counting method still remains widely used because of its sensitivity, and especially in research laboratories where experiments involve cell concentrations close to 1 cell $\cdot \mathrm{mL}^{-1}$. This method is also the most efficient when enumeration of a large range of cell concentrations is required as well as when a specific flora has to be measured in food matrices or under specific technological processes (lethal shock studies or growth curve studies). These experiments require precision, sensitivity, and often a lot of samples with a great number of replicates.

In order to reduce the handling time of the conventional plate-counting method, inoculation or dilution techniques have already been automated or simplified. Gravimetric diluters which weigh samples and dispense the required volume of sol- vent, and spiral plating, which applies a 50- $\mu \mathrm{L}$ sample to the surface of a rotating agar plate, producing a dilution by a factor of 1000 on a single plate [3], are often used in food factories for examination of a great number of samples inoculated on different selective agar media. The micro-colony technique, based upon the reduction of incubation time by examining cultures earlier under magnification, has been applied on a limited basis because it requires considerable care. The Miles-Misra drop plate method is based upon inoculation of accurately calibrated drops of microbial suspension onto the surface of a well-dried agar plate [6]. The agar droplet technique [6] is a refinement of the Miles-Misra method. Although micro-colonies are difficult to interpret (even if counted under magnification), the method produces further savings by using molten agar as the solvent.

The aforementioned methods simplify or automate conventional plate-counting techniques, but still require a competent and alert technician, and, in some cases, purchasing expensive equipment. Fung and Kraft [2] proposed a miniaturization procedure where sample dilutions were done in a Microtiter plate and subsequently multispot-plated on a solid agar surface using a calibrated pipette. Kim and Fung [5] further 
reduced the processing time by using a calibrated multiple-point inoculator to transfer diluted samples to solidified agar. Another improvement was proposed by Casas et al. [1] with an agar overlay procedure that stabilized the samples and improved colony definition.

Here we report on a method providing further refinement in the miniaturization procedure, through rapid transfer of sample dilutions from the 96-well micro-plate into 24-well micro-plates, each well representing a miniaturized Petri dish on which agar can be overlaid. The objective was to evaluate the improvement of this new method in terms of reliability (colony count and interpretation), handling time and material cost.

\section{MATERIALS AND METHODS}

\subsection{Miniaturized method}

Figure 1 presents the schematic principle of this technique applied to a 16-sample size analysis by comparing each step with the conventional method. An aseptic environment and classical microbiology materials are needed. Sample preparation is the same as for the conventional method. A 96-well micro-plate (VWR, Strasbourg, France) was used for the dilution step, from $10^{0}$ to $10^{-5}$ in our example (Fig. 1). Each dilution well received $180 \mu \mathrm{L}$ of buffered peptonewater using an 8-channel automatic pipette. A $100-\mu \mathrm{L}$ amount of each sample homogenate was then deposited on the first or the latter column of the 96-well micro-plate for samples S1 to S8 or S9 to S16, respectively. After homogenization by passing the mix through the pipette tips three times, decimal dilutions were made using an 8-channel pipette: $20 \mu \mathrm{L}$ of each sample homogenate was successively diluted into $180 \mu \mathrm{L}$ of buffered peptone-water, from column 1 to 6 and from column 12 to 7 for S1 to S8 and S9 to S16, respectively. Like for the conventional method, precise dilution required the sterile tips to be replaced after each dilution step. In order to reduce handling time, each 8-tip replacement on the multi-channel pipette was done for one column out of every two from the 96-tip box. The remain- ing tips in the box were used for the subsequent inoculation step.

After the dilution phase, a 24-well micro-plate (VWR, Strasbourg, France) was used for inoculation of $50 \mu \mathrm{L}$ of each dilution of S1, S3, S5 and S7 samples, using an 8-channel pipette, handling tips for one out of every two channels (the remaining tips used in the dilution step) in order to adjust interval spaces between wells from the 96-well micro-plate to those of the 24well micro-plate. Each well of the 24-well micro-plate can be interpreted as a miniaturized Petri dish where micro-organism growth occurs in agar medium. Similarly, dilutions of S2, S4, S6 and S8 were transferred into a second 24-well micro-plate and so on up to the $\mathrm{S} 16$ sample. The analysis of 16 samples hence required the use of four 24-well micro-plates.

Once the inoculation of the 4th 24-well micro-plate was done, $400 \mu \mathrm{L}$ of appropriate agar medium (cooled to $45^{\circ} \mathrm{C}$ ) was then added to each well using an automated pipette (Fischer Bioblock Scientific, Illkirch, France). Dilutions and agar medium were mixed thoroughly by rotating the microplate. After the agar solidified, the 24-well micro-plates were inverted and incubated promptly at the appropriate temperature. After an appropriate incubation time (depending on the micro-organism) the Colony-Forming Units (CFU) were counted without magnification or using a magnifying glass to facilitate reading. Results were expressed as number of CFU per $\mathrm{mL}$ of sample homogenate using the following calculation:

Number of CFU. $\mathrm{mL}^{-1}=$

$\underline{\text { Number of CFU / well } \times \text { dilution factor } \times 1000}$ 50

The detection limit of our miniaturized method was $20 \mathrm{CFU} \cdot \mathrm{mL}^{-1}$ for the $10^{0} \mathrm{dilu}-$ tion well.

\subsection{Evaluation procedures}

\subsubsection{Escherichia coli submitted to a sub-lethal thermic stress}

Escherichia coli $\mathrm{DH} 5 \alpha$ was grown at $37^{\circ} \mathrm{C}$ in Tryptic Soy Broth (VWR, Strasbourg, 


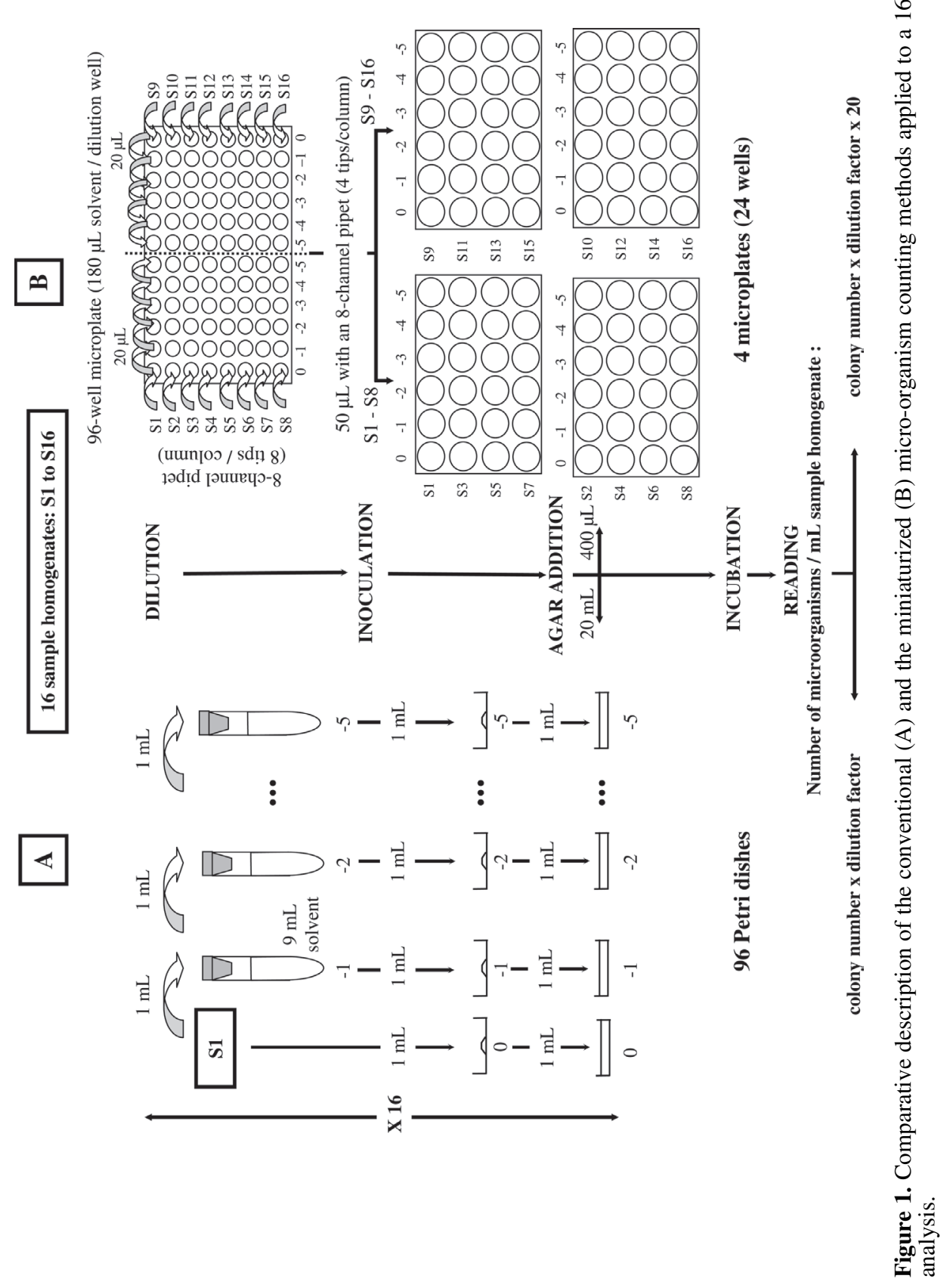


France) for $24 \mathrm{~h}$. One $\mathrm{mL}$ of this pre-culture was transferred into tubes containing $9 \mathrm{~mL}$ pre-warmed fresh medium. Incubation was carried out in a $55^{\circ} \mathrm{C}$ water bath. Two-mL samples were withdrawn after 5, 10 and 15 min of incubation, cooled on ice and used in parallel for the conventional and the miniaturized methods. CFU were counted after 24 hours' incubation on Luria-Bertani agar (10 g.L $\mathrm{L}^{-1}$ Bacto peptone, $5 \mathrm{~g} \cdot \mathrm{L}^{-1}$ Bacto yeast extract, $5 \mathrm{~g} \cdot \mathrm{L}^{-1} \mathrm{NaCl}, 15 \mathrm{~g} \cdot \mathrm{L}^{-1}$ Agar agar, VWR, Strasbourg, France) at $37^{\circ} \mathrm{C}$.

\subsubsection{Milk fermentation}

One liter of milk was inoculated with $4 \mathrm{~mL}$ Lactobacillus bulgaricus reconstituted starter (LB340, Rhodia food, Dangé Saint Romain, France) and $2 \mathrm{~mL}$ Streptococcus thermophilus reconstituted starter (TA060 Rhodia food, Dangé Saint Romain, France). Two-mL samples were transferred into buffered peptone-water after 1,3,4 and $5 \mathrm{~h}$ of incubation at $43^{\circ} \mathrm{C}$ and analyzed by the conventional and the miniaturized methods. CFU were counted after 48 hours' incubation on M17 agar (VWR, Strasbourg, France) at $37^{\circ} \mathrm{C}$ and on MRS agar (AES, Combourg, France) at $43{ }^{\circ} \mathrm{C}$ under anaerobic conditions (Anaerocult A, VWR, Strasbourg, France).

\subsubsection{Spoiled food}

Separate 10 -g portions of commerciallyavailable meat, fish and pastry kept for $24 \mathrm{~h}$ at room temperature were placed in plastic bags including $90 \mathrm{~mL}$ of buffered peptonewater and mixed for $2 \mathrm{~min}$ in a Stomacher (Lab Blender 400, AES, Combourg, France). Total aerobic flora, coliforms and Staphylococcus aureus were enumerated on Plate Count Agar (PCA, VWR, Strasbourg, France, $\left.30{ }^{\circ} \mathrm{C}, 3 \mathrm{~d}\right)$, Deoxycholate Lactose agar (DL, VWR, Strasbourg, France, $37^{\circ} \mathrm{C}, 24 \mathrm{~h}$ ) and Baird Parker agar (BP, VWR, Strasbourg, France, $37^{\circ} \mathrm{C}, 48$ h), respectively.

\subsection{Statistical analysis}

The results (data log-transformed) are reported as means of three replicates. To determine the significance of the differences between the results obtained with the miniaturized method and the conventional one, Student's $t$-test was performed on both sets.

\section{RESULTS AND DISCUSSION}

As shown in Table I, for both the conventional and miniaturized methods, a classical, time-dependent decrease in the cell population of $E$. coli submitted to a $55^{\circ} \mathrm{C}$ heat-shock [4], and classical growth behavior of both types of lactic bacteria during milk fermentation (French standard for yoghurt: NF 04-600) were observed. For both experiments, no significant differences $(P<0.1)$ were found between the two methods. Statistically similar results were also obtained $(P<0.1)$ with both methods applied to spoiled food analysis, showing fish and pastry contamination with a total flora comprising coliforms and Staphylococcus aureus. Staphylococcus aureus was not detected in the meat matrix, whatever the method used. The colony definition was excellent in the miniaturized Petri dishes of the 24-well micro-plates, including the detection of specific halos surrounding Staphylococcus aureus colonies grown in BP agar.

Whatever the type and the origin (laboratory or food) of the micro-organisms, culture conditions (temperature, defined or complex medium), cell number (from 20 to $10^{9}$ cells $\cdot \mathrm{mL}^{-1}$ or $\mathrm{g}^{-1}$ of product), and type of agar medium used for colony development (selective or non-selective), the results obtained with the micro-method were similar to those obtained with the conventional one (no significant difference at $P<0.1)$. Moreover, the rapid agar overlay procedure used in this new miniaturized method allows for good colony interpretation due to rapid stabilization of the sample in the agar medium, while spot-plating techniques induce spreading out of the samples and loss of colony definition [1]. This new method is therefore especially convenient for cultural characterization of several micro-organisms, including halo formation during growth in selective agar media. 
Table I. Comparative results of micro-organism enumeration by the conventional and the miniaturized methods applied to the study of a $55{ }^{\circ} \mathrm{C}$ sub-lethal stress of $E$. coli, growth of $S$. thermophilus and L. bulgaricus in milk, and analysis of spoiled food. No significant differences were found between the two methods $(P<0.1)$ regardless of bacteria, media and incubation times.

Escherichia coli submitted to a $55^{\circ} \mathrm{C}$ sub-lethal stress

\begin{tabular}{lcc} 
Incubation time $(\mathrm{min})$ & Conventional method & Miniaturized method \\
\hline 0 & 9.1 & 9.3 \\
5 & 8.0 & 7.7 \\
10 & 5.8 & 5.6 \\
15 & 4.1 & 3.9 \\
\hline
\end{tabular}

Milk fermentation

Conventional method Miniaturized method

\begin{tabular}{lcccc} 
Incubation time (h) & S. thermophilus & L. bulgaricus & S. thermophilus & L. bulgaricus \\
\hline 0 & 5.5 & 4.3 & 5.7 & 4.1 \\
1 & 6.1 & 4.4 & 6.0 & 4.0 \\
3 & 8.0 & 5.9 & 7.8 & 5.7 \\
4 & 8.7 & 6.9 & 8.8 & 6.9 \\
5 & 8.9 & 7.6 & 8.9 & 7.6 \\
\hline
\end{tabular}

Spoiled food

Conventional method

Miniaturized method

\begin{tabular}{lcccccc} 
Food & Total flora & Coliforms & S. aureus & Total flora & Coliforms & S. aureus \\
\hline Meat & 3.1 & $<1.0$ & $<1.0$ & 3.5 & $<1.3$ & $<1.3$ \\
Fish & 5.7 & 3.3 & 4.5 & 5.7 & 3.3 & 4.4 \\
Pastry & 4.7 & 1.0 & 2.4 & 5.0 & 1.3 & 2.5 \\
\hline
\end{tabular}

In addition, agar overlaying allows for a better development of injured bacteria as compared to their growth on solidified agar surfaces. In this regard, this new miniaturized method is also convenient for cell enumeration in food industries where bacteria could be submitted to specific technological processes (thermic, acid or oxidative shocks, for example) reducing their ability to survey on agar media. The use of sterile tips for each dilution step, low volumes in the tips and an 8-channel pipette decontamination every day avoid the possibility of multi-cross-contaminations.

From a practical point of view, the miniaturized method was assessed for its material cost and the time needed to run it. Table II shows that the advantages of this method over the conventional enumeration method include a reduction in both quantity of materials and handling time needed for overall assay analysis, including medium preparation to material autoclaving. Consequently, the presented technique provides reduction in the overall cost of cell enumeration. Hence, a $74 \%$ decrease in material cost was obtained using the miniaturized method as compared with the conventional one. As a consequence of assay miniaturization, this technique provides (i) a $98 \%$ decrease in the volume of both solvent needed for inoculum dilution and agar growth culture medium; (ii) about a $90 \%$ reduction in the space required for incubation and autoclaving, particularly since four 24-well plates are used with the miniaturized 
Table II. Cost and handling time comparison of the conventional and the miniaturized microorganism counting methods

\begin{tabular}{|c|c|c|c|c|c|c|c|c|}
\hline \multirow[b]{2}{*}{ Consumables } & \multirow[b]{2}{*}{ Type } & \multicolumn{3}{|c|}{ Conventional method } & \multicolumn{3}{|c|}{ Miniaturized method } & \multirow{2}{*}{$\begin{array}{c}\text { Reduction } \\
(\%)\end{array}$} \\
\hline & & Tubes $^{\mathrm{a}}$ & Pipets ${ }^{b}$ & $\begin{array}{c}\text { Petri } \\
\text { dishes }^{\mathrm{c}}\end{array}$ & $\begin{array}{l}\text { 96-well } \\
\text { plates }\end{array}$ & $\begin{array}{l}\text { 24-well } \\
\text { plates }\end{array}$ & tips & \\
\hline & Number & 96 & 96 & 96 & 1 & 4 & 96 & - \\
\hline & Cost $(€)$ & 15.4 & 5.8 & 9.6 & 2.5 & 3.2 & 3.8 & 69 \\
\hline \multirow[t]{2}{*}{ Solvent } & Volume (mL) & & 864 & & & 18 & & 98 \\
\hline & Cost $(€)$ & & 0.04 & & & 0.0008 & & 98 \\
\hline \multirow[t]{2}{*}{ Agar } & Volume (mL) & & 1920 & & & 40 & & 98 \\
\hline & Cost $(€)$ & & 5.76 & & & 0.12 & & 98 \\
\hline Total cost $(€)$ & & & 36.6 & & & 9.6 & & 74 \\
\hline \multirow[t]{2}{*}{$\begin{array}{l}\text { Handling time } \\
(\mathrm{min})\end{array}$} & $\begin{array}{l}\text { Medium preparation } \\
\text { and delivery }\end{array}$ & & 50 & & & 13 & & 74 \\
\hline & $\begin{array}{c}\text { Dilutions and } \\
\text { inoculation }\end{array}$ & & 160 & & & 32 & & 80 \\
\hline \multicolumn{2}{|c|}{ Total handling time (min) } & & 210 & & & 45 & & 78 \\
\hline \multicolumn{2}{|c|}{ Required space for incubation $\left(\mathrm{dm}^{3}\right)$} & & 9.16 & & & 0.98 & & 89 \\
\hline \multicolumn{2}{|c|}{ Required space for autoclaving $\left(\mathrm{dm}^{3}\right)$} & & 14.87 & & & 1.20 & & 92 \\
\hline
\end{tabular}

a 10 -mL tubes; ${ }^{b} 1-\mathrm{mL}$ pipets; ${ }^{\mathrm{c}}$ 90-mm diameter Petri dishes.

method as compared to the 96 Petri dishes used in the conventional method for a 16sample size analysis; moreover, a single 96-well plate replaces the 96 dilution tubes; and (iii) a $78 \%$ reduction in total handling time, because of the ease of use and convenience for the manipulator, allowing for an increase in the number of routine analyses to be processed.

Our miniaturized method is reproducible, with a detection limit close to that of the traditional plate-counting method. Reading and result interpretation do not present any additional complexity for the operator as compared to the conventional method, hence allowing large numbers of cost-and time-effective enumerations to be carried out. Moreover, this technique can be easily improved by developing automation and computerization.

Acknowledgements: We thank B. Francilette, G. Rotin and S. Barolo for able technical assistance. We are grateful to J. Hall for English correction of the manuscript.

\section{REFERENCES}

[1] Casas I.A., Leon N., Izquierdo P., Microtiter technique for enumeration of mesophiles, psychotrophs, and coliforms in raw and pasteurised milk, J. Food Prot. 40 (1977) 795797.

[2] Fung D.Y.C., Kraft A.A., Microtiter method for the evaluation of viable cells in bacterial cultures, J. Appl. Microbiol. 16 (1968) 10361039.

[3] Gilchrist J.E., Donnelly C.B., Peeler J.T., Campbell J.E., Collaborative study comparing the spiral plate and aerobic plate count methods, JAOAC 60 (1977) 807-812.

[4] Jenkins D.E., Schultz J.E., Matin A., Starvation-induced cross protection against heat or $\mathrm{H}_{2} \mathrm{O}_{2}$ challenge in Escherichia coli, J. Bacteriol. 170 (1988) 3910-3914.

[5] Kim S., Fung D.Y.C., Microtiter count method for viable cell counts from pure cultures and food model samples, Food Microbiol. 22 (2005) 595-599.

[6] Sharpe A.N., Jackson A.K., in: Heden C.G., Illeni T. (Eds.), Automation in microbiology and immunology, J. Wiley, New York, USA, 1975, pp. 127-137. 